\title{
Chemical composition, antibacterial and antioxidant activities of Moroccan Daucus carota essential oils
}

\author{
Rachid Ihamdane ${ }^{1}$, Sara Haida ${ }^{2}$, Asmaa Oubihi ${ }^{3}$, Lamyaa Zelmat ${ }^{4}$, Malika Tiskar ${ }^{1}$, Brahim Outemsaa ${ }^{3}$ and \\ Abdelaziz Chaouch ${ }^{1}$ \\ ${ }^{1}$ Department of Chemistry, Organic chemistry, Catalysis and Environment Laboratory, Faculty of Sciences, Ibn Tofail \\ University, Kénitra, Morocco \\ ${ }^{2}$ Department of Chemistry, Advanced Materials and Process Engineering laboratory, Faculty of Sciences, Ibn Tofail \\ University, Kénitra, Morocco \\ ${ }^{3}$ Department of Chemistry, Natural Resources and Sustainable Development laboratory, Faculty of Sciences, Ibn Tofail \\ University, Kénitra, Morocco \\ ${ }^{4}$ Plant Pathology and Post-Harvest Quality laboratory, National Institute of Agricultural Research of Morocco (INRA), \\ Kénitra, Morocco
}

\begin{abstract}
Medicinal and aromatic plants have been widely used for their potential ability to curing diseases and injury. Numerous studies were focused nowadays on the pharmacological proprieties of these plants including the antibacterial and antioxidant activities. In this context, the present study aims to determine the chemical composition of essential oils (EOs) from wild carrot (Daucus carota Linnaeus) and evaluate their and antioxidant and antibacterial activities. The essential oil was obtained by Clevenger apparatus hydro-distillation and analyzed, afterward, using Chromatography-Mass spectrometry (GC-MS). A diffusion technique on agar plates was applied to determine the EOs effect against Gram-positive bacteria, whereas the DPPH radical reduction (1,1-diphényl-2-picrylhydrazy) method was used to estimate the antioxidant activity. Findings analysis identified 57 volatile components during this experiment with a majority of $\alpha$-Pinene $(23,5 \%)$ and $\beta$-Asarone $(16,70 \%)$. Therefore, the tested EOs revealed great inhibitory properties against the Gram-positive bacteria, and an antioxidant potential with IC50 $=73.31 \pm 4.46 \mu \mathrm{g} / \mathrm{mL}$.
\end{abstract}

\section{Introduction}

In recent years, synthetic antibiotics and antioxidants have been widely used in the food industry to prevent microbial growth and delay the oxidation of the fats in foods [1], [2]. However, these additives are considered the main preoccupation as they have negative impacts on human health. In addition, antibiotic resistance presents a significant threat to the global human and environmental ecosystems [3]. Consequently, these difficulties require and encourage, effectively the industry to demand and use new natural resources such as essential oils which are added in food preparation for sensory profiles and longer shelf-life [4]. According to Bakkali et al. [4] and Aghbash et al. [1], Eos are a natural complex of volatile and hydrophobic compounds characterized by a strong odour as Monoterpenes, Sesquerpitenes and Aromatic compounds.

Wild carrot (Daucus carota L.) is a spiny-fruited plant that belongs to the Apiaceae family and grown pushes in Africa, Asia, European moderates regions and North and South America [6]. As reported in several studies, this aromatic plant has many therapeutic benefits including Larvicidal [7], antibacterial [8], [9] and antifungal activities [10].
In Morocco, there has been little research was conducted on the composition of Daucus carota L essential oils. To our knowledge, there are no previous studies that evaluated the antibacterial and antioxidant activities of this essential oil. In this regard, the objective of the present study focused on the determination of essential oil composition extracted from the Daucus carota aerial part collected from the Khessimet region.

\section{Material and Methods}

\subsection{Plant Sampling and essential oil extraction}

Aerial pats of Daucus carota were collected from khémisset region (Morocco) region at flowering stage in June 2019. Identification of the plant was realized by Professor L. Zidane, a botanical researcher in Science Faculty at University Ibn Tofail, Kénitra. For the essential oil extraction, samples were correctly dried in the shadows at room temperature and ground, thereafter, to produce the powder. Using the Clevenger type apparatus [11], a period of 3 hours of Hydro-distillation was taken to generate a return of $0.21 \%$.

\subsection{Essential oil analyses}


Essential oil analysis was performed by dissolving 10 $\mu \mathrm{L}$ of liquid sample in the appropriate volume of chloroform. Volatile compounds profiles were clearly established in the Gas Chromatography-Mass Spectrometry (GC-MS) equipped with Multimode injector and 123-BD11 column $(15 \mathrm{~m} \times 320 \mu \mathrm{m} \times 0,1$ $\mu \mathrm{m})$. A volume of $4 \mu \mathrm{L}$ was injected into $1 / 4$ split mode employing the helium as carrier gas at 3 mL.min-1. The ion source and quadrupole temperatures were set up to 230 and $150{ }^{\circ} \mathrm{C}$, respectively. The oven temperature was adjusted to $30{ }^{\circ} \mathrm{C}$ at the beginning of the program and to $360{ }^{\circ} \mathrm{C}$ at the end. Compounds identification was carried out with NIST 2014 MS Library.

\subsection{Disc-diffusion Assay}

The antibacterial activity of the extracted oil was determined using the disc diffusion method as reported by [12]. Briefly, the bacterial suspension was spread out in Petri dishes containing solid medium Mueller Hinton Agar (MHA). Then, filter paper discs of $6 \mathrm{~mm}$, previously covered with essential oil under sterile conditions, were added to the inoculated plates. After $24 \mathrm{~h}$ of incubation at $37^{\circ}$ C $24 \mathrm{~h}$, the diameters of inhibition growth zones were measured. Ciprofloxacin (5 $\mu \mathrm{g} /$ disc) and amoxicillin $(5 \mu \mathrm{g} / \mathrm{disc})$ were considered as positives controls.

\subsection{Minimum Inhibitory Concentration (MIC)}

To evaluate the minimum inhibitory concentrations (MICs) of EOs, a method described by Oubihi et al. [13] was used. The non-miscibility characteristic of essential oils in water involves their preparation in $0.2 \%$ agar solution to ensure uniform Eos distribution and to achieve effective emulsification. Serie of dilutions were carried out under aseptic condition at $1 / 10 \mathrm{e}, 1 / 25 \mathrm{e}, 1 / 50 \mathrm{e}, 1 / 100 \mathrm{e}, 1 / 200 \mathrm{e}, 1 / 300 \mathrm{e}$ and $1 / 500 \mathrm{e}$ to obtain the final concentrations of $1 / 100$, $1 / 250,1 / 500,1 / 1000,1 / 2000,1 / 3000$ et $1 / 5000$ $(\mathrm{v} / \mathrm{v})$. The plates containing only the culture medium and the $0.2 \%$ agar solution were maintained as controls. The striation of plates was realized using a sterile platinum. The experiments were repeated three times and incubated at $37^{\circ} \mathrm{C}$ for $24 \mathrm{~h}$.

\subsection{Diphenyl-1-picrilhydrazyl (DPPH) radical scavenging test}

The antioxidant activity of the EOs was evaluated based on the DPPH free radical scavenging test according to the method employed by Haida et al. [14] 2020). $2000 \mu \mathrm{L}$ of DPPH ethanolic solution (76 $\mu \mathrm{M}$ ) was mixed with $100 \mu \mathrm{L}$ of oil fractions prepared in ethanol solvent, at different concentrations. The reaction was performed in the dark at room temperature. After 30 minutes, the absorbance was recorded at $517 \mathrm{~nm}$ using a UV-VIS spectrophotometer. The control was prepared under the same conditions of DPPH and ethanol solutions and the ascorbic acid was used as the standard. The percent inhibition of DPPH free radical by samples was determined as follows:

$\%$ of inhibition $=\left(\right.$ Abs $_{\text {Blank }}-$ Abs $\left._{\text {sample }}\right) \times 100 /$ Abs Blank

The IC50 value determining the oil extract concentration required to inhibit $50 \%$ of the initial free radical DPPH was calculated using as the percentage of inhibition points change according to different concentrations.

\section{Results and discussion}

\subsection{Chemical Constituents of Essential Oils}

The chemical class and essential oil compositions were presented in table 1 . Results show that the essential oils from Daucus carota L. are predominantly composed of monoterpenes hydrocarbons with a percentage $42,7 \%$. The major compounds are $\alpha$-pinène (1 23,5 \%), Dehydrosabinene $(1,24 \%)$ et D-Limonene $(2,05 \%)$. The identified second group contains the sesquiterpene hydrocarbons as the most abundant amounts, mainly, $\beta$-bisabolene $(3,93 \%)$, $\beta$ caryophyllene $(0,49 \%)$ et E- $\alpha$ - le bisabolene $(0.46 \%)$. Phenylpropanoïd fraction was dominated by the trans-asarone.

Table 1: Chemical composition of Daucus carota L essential oil

\begin{tabular}{|l|l|c|c|}
\hline No & Component & RT (min) & \% \\
\hline 1 & $\alpha$-Pinene & 2.15 & 23.5 \\
\hline 2 & Camphene & 2.27 & 0.72 \\
\hline 3 & Dehydrosabinene & 2.38 & 1.24 \\
\hline 4 & Pseudolimonene & 2.74 & 7.20 \\
\hline 5 & $1,3,8-p-M e n t h a t r i e n e$ & 3.03 & 0.24 \\
\hline 6 & $\beta$-Myrcene & 3.17 & 0.48 \\
\hline 7 & $1,3,8-p-M e n t h a t r i e n e$ & 3.31 & 0.45 \\
\hline 8 & $\alpha-$ Terpinene & 3.54 & 0.85 \\
\hline 9 & p-Cymene & 3.71 & 1.02 \\
\hline 10 & D-Limonene & 3.80 & 2.05 \\
\hline 11 & E)- $\beta$-Ocymene & 4.17 & 0.18 \\
\hline 12 & $\beta$-Ocymene & 4.39 & 0.13 \\
\hline 13 & $\gamma$-Terpinene & 4.49 & 1.24 \\
\hline 14 & (E)- $\beta$-Terpinolene & 5.14 & 0.74 \\
\hline 15 & alpha.-Campholenal & 5.23 & 0.20 \\
\hline 16 & Linalool & 5.67 & 2.87 \\
\hline 17 & Nonanal & 5.74 & 0.27 \\
\hline 18 & $\alpha$-Camphenal & 6.02 & 0.98 \\
\hline 19 & Pinocarveol & 6.25 & 1.15 \\
\hline 20 & cis-Verbenol & 6.44 & 0.46 \\
\hline 21 & trans-Verbenol & 6.55 & 1.07 \\
\hline 22 & $\alpha-P h e l l a n d r e n-8-o l$ & 6.60 & 0.73 \\
\hline 23 & Pinocarvone & 6.81 & 0.53 \\
\hline 24 & $\alpha$-Phellandren-8-ol & 7.16 & 1.70 \\
\hline 25 & L-4-terpineneol & 7.31 & 1.84 \\
\hline 26 & Myrtenal & 7.66 & 0.72 \\
\hline 27 & $\alpha-$-Terpineol & 7.71 & 0.82 \\
\hline & & & \\
\hline
\end{tabular}




\begin{tabular}{|l|l|c|c|}
\hline 28 & Myrtenol & 7.85 & 0.43 \\
\hline 29 & S-Verbenone & 8.02 & 0.60 \\
\hline 30 & Carveol II & 8.51 & 0.31 \\
\hline 31 & (Z)-Geraniol & 9.65 & 0.30 \\
\hline 32 & Bornyl acetate & 10.07 & 0.22 \\
\hline 33 & Caryophyllene & 13.79 & 0.49 \\
\hline 34 & Humulene & 14.68 & 0.48 \\
\hline 35 & Germacrene D & 15.39 & 0.82 \\
\hline 36 & Bicylogermacrene & 15.72 & 0.42 \\
\hline 37 & (Z)-Methyl eugenol & 16.26 & 2.40 \\
\hline 38 & $\beta$-Bisabolene & 16.32 & 3.96 \\
\hline 39 & -Cadinene & 16.46 & 0.27 \\
\hline 40 & $\begin{array}{l}\text { Cadala-1(10),3,8- } \\
\text { triene }\end{array}$ & 16.68 & 0.41 \\
\hline 41 & $\begin{array}{l}\text { 2H- } \\
\text { Cycloprop[c]indene- }\end{array}$ & 16.84 & 0.28 \\
& $\begin{array}{l}\text { h,3(3ah)-dione, } \\
\text { hexahydro-3a,7,7- }\end{array}$ & & \\
\hline 42 & (E)- $\alpha$-Bisabolene & 17.00 & 0.46 \\
\hline 43 & Mint oxide & 17.70 & 0.47 \\
\hline 44 & Caryophylene oxide & 17.35 & 1.58 \\
\hline 45 & Elemicin & 17.45 & 0.79 \\
\hline 46 & Carotol & 17.64 & 1.10 \\
\hline 47 & Humulene epoxide II & 17.84 & 0.59 \\
\hline 48 & $\begin{array}{l}\text { 2-Isopropylidene-3- } \\
\text { methylhexa-3,5- } \\
\text { dienal }\end{array}$ & 17.93 & 1.00 \\
\hline 49 & $\alpha-$-Costol & 18.08 & 0.48 \\
\hline 50 & Isospathulenol & 18.38 & 2.05 \\
\hline 51 & Asarone & 18.60 & 1.49 \\
\hline 52 & Prezizaene & 18.70 & 0.35 \\
\hline 53 & (+) - $\alpha$-himachalene & 18.77 & 0.53 \\
\hline 54 & $\beta$-Asarone & 19.68 & 16.70 \\
\hline 55 & (R)-Cryptomerione & 20.07 & 0.21 \\
\hline & & & \\
\hline
\end{tabular}

\begin{tabular}{|l|l|l|l|}
\hline 56 & Phytone & 21.98 & 0.17 \\
\hline 57 & Emersol 140 & 23.79 & 0.26 \\
\hline
\end{tabular}

\subsection{The antibacterial activity}

The essential oil antibacterial activity findings (Table 2), showed that the Daucus carota essential oil revealed an important reduction of the Gram-positive bacteria growth. The highest inhibitory activity was exhibited especially against the Staphylococcus aureus and Staphylococcus epidermidis which present, at the time, a resistance to the ceftriaxone and penicillin antibiotics. A similar results were reported by Gaglio et al. [15]. Moreover, Acinetobacter baumannii, Klebsiella pneumonia, Escherichia coli and Enterobacter cloacae were found non-sensitive to the studied essential oil components. In agreement, several studies demonstrate that Gram-positive bacteria are more sensitive to the actions of the essential oils than Gram-negative bacteria which appear more tolerant [13], [16].

Table 3 representing the minimum inhibitory concentration of the studied essential oil. As shown, the levels of antibacterial activity range from $1 / 500$ $\mathrm{v} / \mathrm{v}$ to $1 / 100 \mathrm{v} / \mathrm{v}$. In this regard, $1 / 500 \mathrm{v} / \mathrm{v}$ was defined as the lowest concentration at which the Staphylococcus aureus and Staphylococcus epidermidis are inhibited (Figure 1). Consequently, this study performed an effective antibacterial activity of Daucus carota essential oil against Grampositive bacteria. In previous reports, this efficiency is strictly related to their chemical composition, such as $\alpha$-pinène, (Z)-Methyl eugenol and elemicin known as potential antimicrobials [17-20].

Table 2 : Antibacterial activity of Daucus carota. L essential oil.

\begin{tabular}{|c|c|c|c|}
\hline \multirow[t]{3}{*}{ Microorganisms } & \multicolumn{3}{|c|}{ Inhibition zone diameter (mm) } \\
\hline & \multirow{2}{*}{$\begin{array}{c}\text { Essential oil } \\
\text { Daucus carota }\end{array}$} & \multicolumn{2}{|c|}{ Antibiotics } \\
\hline & & Penicillin & Ceftriaxone \\
\hline \multicolumn{4}{|l|}{ BACTERIES } \\
\hline \multicolumn{4}{|l|}{ Gram-positive } \\
\hline Staphylococcus aureus & $11 \pm 00$ & NA & NA \\
\hline Staphylococcus epidermidis & $10.66 \pm 0.44$ & NA & NA \\
\hline \multicolumn{4}{|l|}{ Gram-negative } \\
\hline Acinetobacter baumanii & $00 \pm 00$ & NA & NA \\
\hline Klebsiella pneumonia & $00 \pm 00$ & NA & NA \\
\hline Enterobacter cloacae & $00 \pm 00$ & NA & NA \\
\hline Escherichia coli & $00 \pm 00$ & NA & NA \\
\hline
\end{tabular}

NA : non active. 
Table 3: Minimum inhibitory concentration (MIC) of Daucus carota.L essential oil

\begin{tabular}{|c|c|c|c|c|c|c|c|c|}
\hline & $1 / 100 v / v$ & $1 / 250 v / v$ & $1 / 500 v / v$ & $1 / 1000 v / v$ & $1 / 2000 v / v$ & $1 / 3000 v / v$ & $1 / 5000 v / v$ & control \\
\hline & $D C$ & $D C$ & $D C$ & $D C$ & $D C$ & $D C$ & $D C$ & $D C$ \\
\hline \multicolumn{9}{|l|}{ BACTERIES } \\
\hline \multicolumn{9}{|l|}{ Gram-positive } \\
\hline $\begin{array}{l}\text { Staphylococcus aureus } \\
\text { Staphylococcus }\end{array}$ & - & - & - & + & + & + & + & + \\
\hline epidermidis & - & - & - & + & + & + & + & + \\
\hline
\end{tabular}

(-): inhibition ; (+) : croissance; DC : Daucus carota

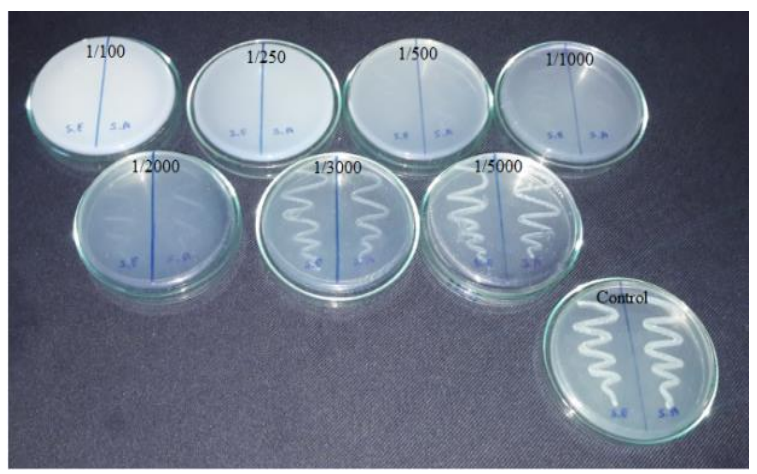

Fig.1. Minimum inhibitory concentration (MIC) of Daucus carota.L essential oil. against Staphylococcus aureus (S.A) and Staphylococcus epidermidis (S.E) after incubation period of $24 \mathrm{~h}$ at $37^{\circ} \mathrm{C}$.

\subsection{Antioxidant activity}

The concentration-response curve representing the inhibitory effect of $D$. carota essential oil on DPPH stabilizer group was illustrated in figure 2. The data were expressed as mean \pm standard deviation and three repetitions were performed each time. According to our knowledge, no data for the antioxidant activity of the studied essential oil is available in the literature. However, some studies contributed to characterize the effect carrot extract were reported their antioxidant activity [21].

The essential oil antioxidant effect was determined by IC50 values calculated from equations of lines reporting in Figure 2. The same method was used to measuring the free radical scavenging of ascorbic acid. The low value of IC50 indicates effectively, the strongest activity of the tested sample. Generally, the difference of the IC50 values found for EOs due essentially to the variability of their chemical components. In this study, Daucus carota essential oil showed lower antioxidant activity (IC50 $=73.31 \pm 4.46 \mu \mathrm{g} / \mathrm{mL})$ than that of ascorbic acid (IC50 $=0.095 \pm 0.012 \mu \mathrm{g} / \mathrm{mL})$. This can be attributed to the absence of phenolic compounds, and to the presence of $\alpha$-Pinene (23.5\%) which has been reported to exhibit poor antioxidant activities [22].
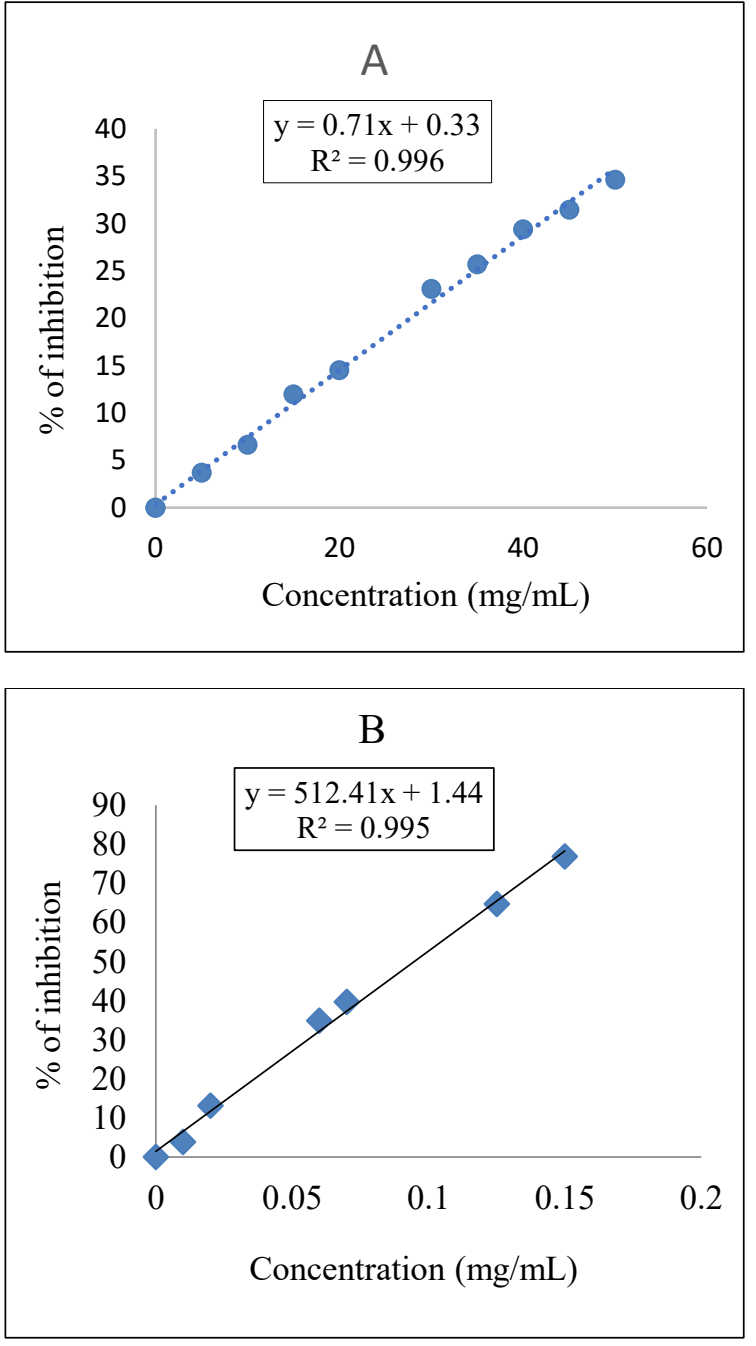

Fig.2. DPPH radical reduction at different concentrations of Daucus carota essential oil (A) and ascorbic acid (B).

\section{Conclusion}


In the present study, we contributed to the valorization of wild carrot by studying the relationship between their chemical composition and their biological activities. The qualitative analysis of essential oils was realized using the Gas Chromatography-Mass Spectrometry (GC-MS). These analyses allowed us to identify 57 components dominated by $\alpha$-Pinène $(23.5 \%)$ and $\beta$ Asarone $(16,70 \%)$. Daucus carota essential oil showed low antioxidant activity, whereas, the evaluation of the antibacterial activity revealed an effective antibacterial effect against the Gram-positive bacteria, dependant dose, on Staphylococcus aureus strain. These preliminary findings are very important and encouraging us to pursue an investigation on this plant

\section{References}

[1] B.N. Aghbash, M. Pouresmaeil, G. Dehghan, M.S. Nojadeh, H. Mobaiyen, F.Maggi, Foods, 9, 494 (2020)

[2] A. Bensid, N. El Abed, A. Houicher, J.M. Regenstein, et F. Özogul, Food Sc. and N, 9, 17 (2020)

[3] I. Nait Irahal, F. Hmimid, F.A. Lahlou, A. Errami, I. Guenaou, I. Diawara, M. KettaniHalabi, S. Fahde, L. Ouafik, N. Bourhim, Eur J Interg Med, 35 (2020)

[4] D. Teneva, R. Denkova-Kostova, B. Goranov, Y. Hristova-Ivanova, A. Slavchev, Z. Denkova, G. Kostov. Z. Naturforsch. C., 74 (2019)

[5] F. Bakkali, S. Averbeck, D. Averbeck, M. Idaomar, Food Chem. Toxicol., 46 (2008)

[6] W. N. Shebaby, C. F. Daher, M. El-Sibai , K. Bodman-Smith1, A. Mansour, M. C. Karam, M. Mroueh, Pha Bio, 53 (2015)

[7] E. J. Muturi, K. Doll, J. L. Ramirez, et A. P. Rooney, J. Med. Entomol., 56 (2019).

[8] R. Gaglio, M. Barbera, A. Aleo, I. Lommatzsch, T. La Mantia, et L. Settanni, Chem. Biodiversity, 14 (2017).

[9] D. Luc, B. Jean Michel, L. Vanina, M. Alain, B. Liliane, et B. Jean Michel, Molecules, 25 (2020)

[10] A. Tabet Zatla, M. E. A. Dib, N. Djabou, F. Ilias, J. Costa, A. Muselli, J. Essent. Oil Res., 29 (2017)

[11] A. Hajib, I. Nounah, A. Oubihi, H. Harhar, S. Gharby, B. Kartah, K. Bougrin, Z. Charrouf, J. Essent. Oil-Bear. Plants, (2020)

[12] A. Oubihi, I. Ouryemchi, I. Nounah, K. Tarfaoui, H. Harhar, M. Ouhssine, Z. Guessous, Adv. Tradit. Med., 20 (2020)

[13] H. Jaber, A. Oubihi, I. Ouryemchi, R. Boulamtat, A. Oubayoucef, B. Bourkhiss, M. Ouhssine, Biochem. Res. Int, 2021 (2021)

[14] S. Haida, A. Kribii, A. Kribii, S. Afr. J. Bot., $131(2020)$
[15] R. Gaglio, M. Barbera, A. Aleo, I. Lommatzsch, T. La Mantia, et L. Settanni, Chem. Biodiversity, 14 (2017)

[16] L. Mayaud, A. Carricajo, A. Zhiri, G. Aubert, Lett. Appl. Microbiol., 47 (2008)

[17] H.J.D. Dorman, S. G. Deans, J. Appl. Microbiol., 88 (2000)

[18] H. Marzouki, A. Khaldi, D. Falconieri, A. Piras, B. Marongiu, P. Molicotti, S. Zanetti, Nat. Prod. Commun., 5 (2010)

[19] M. Soković, D. Stojković, J. Glamočlija, A. Ćirić, M. Ristić, et D. Grubišić, Pharm. Biol., 47 (2009)

[20] A.C. Tavares, M.J. Gonçalves, C. Cavaleiro, M.T. Cruzc, M.C. Lopes, J. Canhoto, L.R. Salgueiro, J. Ethnopharmacol., 119 (2008)

[21] H. Mohammedi, S. Mecherara-Idjeri, Y. Foudil-Cherif, A. Hassani, J. Essent. Oil-Bear. Plants, 18 (2015) 